\title{
The Warren Court: Rediscovering the Link Between Law and Culture*
}

\author{
Morton J. Horwitz†
}

Europeans frequently observe that there has always been an absence of concern with political culture in the Anglo-American intellectual tradition. This is not strictly so. It is true that the triumph of Benthamism in the political and legal thought of nineteenth century England was accomplished by defeating historical and prescriptive modes of thought and elevating abstract universalism to the forefront. ${ }^{1}$ Yet, Burke's own attack on the abstract universalism of the French Revolution ${ }^{2}$ was itself put forth in the name of culture, history and prescription. In nineteenth century England, attention to the concrete, to the particular-to context, social custom, and the weight of history-was put forth by conservatism against the Party of Reform. ${ }^{3}$ It was the essence of Sir Henry Maine's attack on Benthamism. Maine's turn to legal anthropology was offered for the purpose of developing a Darwinian theory of evolutionary customary law as an alternative to the abstract universalism of Benthamism. In the practical politics of nineteenth century English law reform, social engineering through parliamentary legislation became the chosen path of reform while control of common law modes of thought continued to be the turf of Blackstonian and Burkean conservatism. ${ }^{5}$

On the Continent, attention to political culture was initially rooted in the prescriptive or customary claims of the seventeenth century aristocracy in reaction to the centralizing absolute monar-

* Copyright 1988 by Morton J. Horowitz.

$\dagger$ Charles Warren Professor of American Legal History, Harvard Law School.

1 Jeremy Bentham, A Fragment On Government, esp. 118-19 (Clarendon Press ed. 1891); Elie Halévy, The Growth of Philosophical Radicalism (1928).

2 Edmund Burke, Reflections on the Revolution in France (Thomas H.D. Mahoney ed. 1955).

3.W. Gough, Fundamental Law in English Constitutional History 203-206 (1955).

- Henry Sumner Maine, Ancient Law: Its Connection With The Early History Of Society, And Its Relation To Modern Ideas 113-16 (First American ed. 1864). See also, Henry Sumner Maine, Popular Government 82-88 (1897).

- Franz Neumann, The Democratic and the Authoritarian State 22-68 (1957). 
chy. ${ }^{6}$ These eventually blended into the eighteenth century development of ideas of republican government as an alternative to absolute monarchy. Montesquieu looked back to Machiavelli and the ancients as a source of ideas for understanding how social conditions affect the character of governmental institutions. ${ }^{7}$

But the results of the French Revolution showed the indeterminacy of any close correlation between political culture and politics. The French Revolution shattered any easy identification of existing society with the natural order of things and, for a time, revealed, as all revolutions reveal, the contingent and socially constructed character of political institutions. As in England, the party of middle class reform largely turned to abstract universalism in the Declaration of the Rights of Man and Kantian philosophy. ${ }^{8}$ The Monarchist Party of Reaction turned to history and prescription. And the Socialists discovered political sociology. ${ }^{9}$

One of the most striking features of mainstream American legal and political thought has been its lack of attention to political culture or to the social basis of politics.

- Michael Walzer, The Revolution of the Saints 68-92 (1965) (discussing the French Huguenots); Robert W. Gordon, Historicism in Legal Scholarship, 81 Yale L.J. 1017, 1025 (1981) (seventeenth century lawyers relegated "natural-law thinking" to "the margins of elite legal thought by shifting the center of study to positive law-the specific legal practices of actual societies" and developed "a self-consciously inductive method for deriving legal principles from experience") (footnote omitted).

3 Baron de Montesquieu, The Spirit of the Laws (Hafner Press ed. 1949). For an example of direct recourse by Montesquieu to Machiavelli and the ancients, see id at 1:76-79.

- This reading of Kant, which is surely the way it "turned out," is itself contingent. Kant was inspired by Rousseau. Ernst Cassirer, The Question of John Jacques Rousseau 58 (Peter Gay trans. 1954). Rousseau's contemporary, Diderot, in his Encyclopedia, represented another strand that combined sociology and practical utilitarianism. Arthur M. Wilson, Diderot: The Testing Years, 1713-1759 73-82 (1957). After Montesquieu, Rousseau is arguably the other eighteenth century French thinker who turned to political culture to understand politics. Émile Durkheim, Montesquieu et Rousseau: Précurseurs de la Sociologie 196-97 (1953). Tocqueville himself wrote in an 1836 letter, "[t]here are three men with whom I commune a little every day; they are Pascal, Montesquieu, and Rousseau." Quoted in Richard Herr, Tocqueville and the Old Regime 48 (1962).

In short, Kantian abstract universalism is not inherent in Kant but was itself a creature of nineteenth century liberal political culture as it reacted to the more radical sociologicalhistorical method of Hegel.

- In this brief sketch, I could not begin to prove this proposition. Clearly, the official "founder" of political sociology, Auguste Comte, was not a Socialist. His influence was on Saint Simon and Fourier, two of the founders of Socialism. Comte's relation to Socialism is similar to Hegel's relationship to Marxism. Both Comte and Hegel were led to sociological and historical modes of thought by conservative impulses. But because their genius transcended their immediate politics, their method was available to socialist and reactionary alike. Louis Dumont, Essays on Individualism: Modern Ideology in Anthropological Perspective 97-103 (1986). See generally, Raymond Aron, 1 Main Currents In Sociological Thought (1965). 
In The Liberal Tradition in America, ${ }^{10}$ Louis Hartz argued that the "turn to society" of post-French revolutionary European social thought was the product of a dialogue between a reactionary tradition, which sought to return to a feudal society composed of fixed statuses and hierarchies, and of an emergent Socialism, which focused on the "social question" in order to transform society. For Hartz, the explanation of why there was no American Tocqueville was the absence of a feudal, pre-liberal tradition in America.

The recent rediscovery of a Republican (as opposed to a Lockean liberal) tradition ${ }^{11}$ in American revolutionary thought means that there was a clear alternative non-feudal intellectual tradition, before Socialism, that focused on political culture or on the social basis of politics. Though there are clear connections between early Republicanism and medieval conceptions of fixed statuses and hierarchies, ${ }^{12}$ one of the central recent historiographical discoveries is how these ideas were transformed during the American revolutionary debates into an indigenous American Republicanism. ${ }^{13}$ Indeed, Tocqueville's fascination with American society derived from his own discovery of previously undreamed of Republican possibilities being actualized in America. ${ }^{14}$

Hartz's failure to see that there was a real post-feudal alternative to a radically individualistic Lockean liberalism was itself a latter-day reflection of the defeat of Republican ideology during the nineteenth century and its marginalization into utopian communalism, ${ }^{16}$ abolitionism, ${ }^{16}$ labor protest, ${ }^{17}$ populism $^{18}$ or social gospel Christianity. ${ }^{10}$

${ }^{10}$ Louis Hartz, The Liberal Tradition in America (1955). For the points discussed below, see id. at 6,78 .

${ }^{21}$ Morton J. Horwitz, Republicanism And Liberalism In American Constitutional Thought, 29 Wm. \& Mary L.Rev. 57, 58 n.7 (1987) (citing works on Republican tradition).

12 Frank I. Michelman, Foreward: Traces Of Self-Government, 100 Harv.L.Rev. 4, 37 and nn.184, 185 (1986).

${ }^{23}$ Gordon S. Wood, The Creation of the American Republic 1776-1787 567-92 (1969) ("The Relevance and Irrelevance of John Adams").

14 Morton J. Horwitz, Tocqueville and the Tyranny of the Majority, 28 Rev.Pol. 293, 295 (1966).

${ }^{15}$ Rosabeth Moss Kanter, Commitment and Community: Communes and Utopias in Sociological Perspective (1972).

${ }^{18}$ Eric Foner, Free Soil, Free Labor, Free Men: The Ideology of the Republican Party Before the Civil War 302-304 (1970).

${ }^{17}$ Sean Wilentz, Chants Democratic: New York City \& the Rise of the American Working Class, 1788-1850 237-48 (1984).

18 Lawrence Goodwyn, Democratic Promise: the Populist Movement in America (1976).

19 Sydney E. Ahlstrom, A Religious History of the American People 785-804, 921-23 (1972). 
But the greatest casualty of the lost tradition was that it produced a widespread belief that disembodied post-Benthamite philosophy was most naturally suited to the Anglo-Saxon character. Yet, once we see that not only was Adam Smith an important part of the Republican tradition from Montesquieu to Tocqueville, ${ }^{20}$ but that many Americans after 1776 were themselves interested in "the social question"- the relationship between social equality and political equality-we are in a position to realize that, in 1789, there were many potential Tocquevilles in America and that Tocqueville himself enriched his own understanding of Republicanism during his trip to America. Thomas Jefferson's ideal of a relatively equal society of yeoman farmers as the most desirable social basis of a free society found many theoretical formulations during the revolutionary era. The dominant discussion during the debates over the ratification of the Constitution about whether there could be free government over a large territory ${ }^{21}$ was closely connected to traditional Republican belief in the necessity of a relatively equal and homogeneous society that might produce civic virtue.

The entire prior history of Republican thought was based on the assumption that only small Republics-whether the Greek polis, the Italian city-state, the Oceana of Harrington, Rousseau's Republic of Geneva, or the American states-could maintain free government and political equality. ${ }^{22}$ Thus, the single most audacious and original move of Madison and Hamilton in The Federalist was to reverse the weight of historical argument for free government and to insist that freedom is better secured through government over a large territory.

Indeed, the great contribution of Madisonian liberalism was to concede the inevitability of a multiplicity of factions in society while redirecting the focus of political thought towards institutions that could constrain and channel their "dangerous" tendencies. ${ }^{23}$ Politics was no longer to be concerned with the Republican goal of civic virtue or with the creation of small republics founded on a

${ }^{20}$ Horwitz, $29 \mathrm{Wm}$. \& Mary L.Rev. at 65 (cited in note 11); Garry Wills, Inventing America: Jefferson's Declaration of Independence 129-30, 209, 232, 254, 289 (1978).

${ }^{21}$ Wood, Creation at 499-500, 504-5, 527 (cited in note 13). The discussion was also critical during the Revolutionary era. Bernard Bailyn, The Ideological Origins of the American Revolution 281-82, 288 (1973). Bailyn summarizes the ideas of Charles Inglis, who opposed the Declaration of Independence: "[P]opular governments can survive only in small territories where inhabitants form a homogenous community with a unified economic interest." Id. at 288.

22 J.G.A. Pocock, The Machiavellian Moment: Florentine Political Thought and the Atlantic Republican Tradition (1975).

2s Federalist 10, in Benjamin Fletcher Wright, ed., The Federalist 129, 131-33 (1961). 
relatively homogeneous population. Conceptions of the legitimacy of religious pluralism had emerged before those of political pluralism. And just as the proponents of religious toleration had urged that the substance of a man's thoughts and the quality of his conscience were private and thus irrelevant to politics, ${ }^{24}$ so too did Madisonian liberalism lead to the same privatized versions of political virtue. ${ }^{25}$ The real novelty of Madisonian liberalism is in its view that pluralism is either inevitable or desirable and that the task of politics is to create institutions geared to accepting and constraining that reality.

The triumph of Madisonian liberalism thus eventually produced the virtually exclusive institutionalist focus of American political thought as well as its "legalistic" mindset. Separation of powers, judicial review, and federalism became the unquestioning starting point for all subsequent political and constitutional reflection in America.

The substantive character of political culture and social relations were no longer the source of ideas about the good society. Instead, the Newtonian mechanics of institutional balance became the dominant mode of American political discourse. ${ }^{26}$ Process-oriented thought replaced substantive interest in the quality of political culture.

The result has been a tradition of political discourse that has almost totally ignored the relationship between society and politics, the very question that was central to virtually all political theory at the time of the American Revolution. Indeed, by the late nineteenth century it had developed into the dominant view of the Lochner ${ }^{27}$ court that there was no relevant relationship between political and social equality. ${ }^{28}$

This sharp distinction between the political and the social has usually been structured in American legal thought in terms of the public-private distinction ${ }^{29}$ or, since the passage of the Civil War

24 See John Locke's four letters on toleration, in 6 The Works of John Locke (new ed. corrected 1823).

${ }^{25}$ See Albert O. Hirschman, The Passions and the Interests: Political Arguments for Capitalism before Its Triumph 129-30 (1977) (discussing the civic virtue of pursuing private economic interests as a feature of liberalism generally, not simply Madisonian liberalism).

${ }^{26}$ Michael Kammen, A Machine that Would Go of Itself: The Constitution in American Culture 16-19 (1986).

${ }^{27}$ Lochner v. New York, 198 U.S. 45 (1905).

${ }^{28}$ Coppage v. Kansas, 236 U.S. 1, 17 (1915) ("No doubt, wherever the right of private property exists, there must and will be inequalities of fortune . . . .").

28 See articles collected in University of Pennsylvania Law Review symposium on the Public/Private Distinction, 130 U.Penn.L.Rev. 1289 (1982). 
Amendments, around the question of state action. The Lochner court increasingly articulated conceptions of neutrality which took the liberal state of political culture as "given" and, now, beyond fundamental change. ${ }^{30}$ Thus, social inequality or discrimination were irrelevant to questions involving the public sphere. For example, the only reason why blacks felt stigmatized by separate but equal facilities, according to Plessy $v$. Ferguson, ${ }^{31}$ was that they had "chosen" to put such an invidious interpretation on otherwise "neutral" social preferences.

But nevertheless the one area in which the American liberal tradition has never been entirely able to suppress the relevance of political culture has been race. ${ }^{32}$ Slavery was regarded as a social disease that undermined free institutions by many antebellum thinkers, ${ }^{33}$ not only abolitionists. And since the decision in Brown $v$. Board of Education ${ }^{34}$ it once again has been impossible entirely to separate social domination from political domination.

From this perspective, the Warren Court can be seen to have reintroduced political culture into mainstream legal thought for the first time since the debate over slavery and the subsequent marginalization of a Republican vision with the defeat of Reconstruction. The Warren Court also drew on the earlier efforts of Sociological Jurisprudence and Legal Realism ${ }^{35}$ to insist that legal rules cannot be evaluated outside of a social context. The Brandeis Brief, ${ }^{36}$ which defended the constitutionality of maximum hour laws for women in terms of the social reality of factory work for women, was a forerunner of the controversial footnote in Brown describing the sociological effects of segregation on black school children. ${ }^{37}$ Similarly, the unwillingness of the Supreme Court in

so Morton J. Horwitz, History and Theory, 96 Yale L.J. 1825, 1826-27 (1987).

31 Plessy v. Ferguson, 163 U.S. 537, 551 (1896).

s2 Morton J. Horwitz, The Jurisprudence of Brown and the Dilemmas of Liberalism, 14 Harv.C.R.-C.L.L.Rev. 599, 608-9 (1979) ("At the foundation of the liberal emphasis on individualism is the view that the only legitimate criteria for judging an individual are his own energy and ability. ... [Yet] [r]ace in this country has always stood as a constant reminder of the fact that each individual is not judged solely as an individual.").

ss David Brion Davis, The Problem of Slavery in the Age of Revolution, 1790-1823 (1975).

s4 Brown v. Board of Education, 347 U.S. 483 (1954).

ss Edward A. Purcell, Jr., The Crisis of Democratic Theory 74-94 (1973) (discussing ideas advanced by Sociological Jurisprudence and Legal Realism).

${ }^{36}$ Louis D. Brandeis, Brief For Defendant In Error, Muller v. Oregon, 208 U.S. 412 (1908), in Philip B. Kurland and Gerhard Casper, eds., Landmark Briefs And Arguments Of The Supreme Court Of The United States: Constitutional Law 63-178 (1975).

${ }^{\text {s7 }}$ Brown, 347 U.S. at $494 \mathrm{n} .11$ (cited in note 34 ). 
Shelley $v$. Kraemer ${ }^{38}$ to uphold racially restrictive covenants on the basis of the public-private distinction is a forerunner of many Warren Court decisions watering down the state action requirement for funding unconstitutional discrimination. The Court's understanding of the existence of a systemic culture of racism rejected any appeal to "neutral principles" based on a supposed sharp separation between discrimination in public and private realms.

After Brown, many of the most important decisions of the Warren Court can be understood as a rediscovery of the inseparable connection between political culture and political equality. The recognition of the claims of women, of sexual, religious and cultural minorities, of the marginal and the outcast-illegitimates, aliens, prisoners, criminal defendants, indigents, the homeless, welfare recipients-reflects an understanding of the negative connection between social oppression and political freedom.

The resistance to such an understanding continues not only throughout the abstract universalism of the neo-Kantian tradition $^{39}$ but through the continuing vitality of the public-private distinction and the refusal inherent in it to understand oppression as structural and systemic -in a word, as rooted in culture.

Thus, one can see the Warren Court as transforming the cultural premises of American liberalism in much the same way as early Progressive legal thought transformed its economic premises. Just as "freedom of contract" can be understood not as freedom at all but as an organized form of domination of the weak by the strong, so too, for example, does discrimination come to be understood not as the exercise of random, individualized, social preferences but as a structured cultural form, not very different from state action itself.

Just as corporate concentration at the turn of the century undermined any convincing distinction between private power and public, the rise of a mass media culture forces us to abandon ideas of the private character of speech-and of pornography-that emerged in an earlier age under more decentralized forms of

${ }^{38}$ Shelley v. Kraemer, 334 U.S. 1, 19 (1948) ("We have no doubt that there has been state action in these cases in the full and complete sense of the phrase. . . . [B]ut for the active intervention of the state courts, supported by the full panoply of state power, petitioners [as purchasers of property from willing sellers] would have been free to occupy the properties in question without restraint.").

${ }^{38}$ For examples of recent work in this tradition, see Richard A. Epstein, Takings: Private Property and the Power of Eminent Domain (1985); Charles Fried, Contract as Promise: A Theory of Contractual Obligation (1981); Charles Fried, Right and Wrong (1978). 
communication.

The rediscovery of political culture has thus revived all of the issues that began to be marginalized with the triumph of Madisonian liberalism. It may even be imaginable that, a century and a half later, America will finally bring forth its own Tocqueville, who, inspired by the Republican tradition, will seek once again to understand the relationship between culture and democracy. 